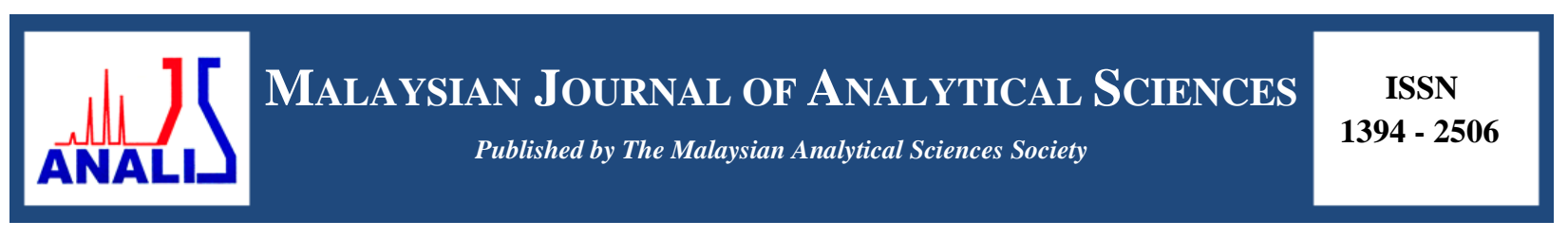

\title{
ISOLATION OF FLAVONOLS FROM THE STEMS OF MALAYSIAN Uncaria cordata var. ferruginea (BLUME) RIDSD.
}

\section{(Pemisahan Flavonol dari batang Uncaria cordata var. ferruginea (Blume) Ridsd. Malaysia)}

\author{
Nur Hakimah Abdullah ${ }^{1}$, Fatimah Salim ${ }^{2,3}$, Rohaya Ahmad ${ }^{1,2} *$ \\ ${ }^{I}$ Faculty of Applied Science, \\ Universiti Teknologi MARA, 40450, Shah Alam, Selangor, Malaysia \\ ${ }^{2}$ Atta- ur-Rahman Institute for Natural Products Discovery, \\ Universiti Teknologi MARA Kampus Puncak Alam, 42300 Bandar Puncak Alam, Selangor, Malaysia \\ ${ }^{3}$ Center of Foundation Studies, \\ Universiti Teknologi MARA, Dengkil Campus, 43800 Dengkil, Selangor, Malaysia
}

*Corresponding author: rohayaahmad@salam.uitm.edu.my

Received: 24 February 2015; Accepted: 27 October 2015

\begin{abstract}
Continuing our interest in the genus, a phytochemical investigation on Uncaria cordata var. ferruginea collected from Hutan Pasir Raja, Malaysia has been carried out. Two flavonols known as quercetin and kaempferol were isolated from the methanolic stem extract of this plant along with other phenolic compounds and terpenes. The two flavonols are reported for the first time from this species. The structure of the compounds were elucidated on the basis of spectroscopic data, mostly 1D-NMR, 2DNMR as well as comparison with literature.
\end{abstract}

Keywords: flavonoid, flavonol, kaempferol, quercetin, Uncaria cordata

\begin{abstract}
Abstrak
Dalam meneruskan minat kami terhadap genus ini, satu kajian fitokimia ke atas Uncaria cordata var. ferruginea yang diambil dari Hutan Pasir Raja, Malaysia telah dijalankan. Dua flavonol dikenali sebagai quercetin dan kaempferol telah diasingkan daripada ekstrak metanol bahagian batang tumbuhan ini bersama sebatian fenolik lain dan terpena. Kedua-dua flavonol ini dilaporkan buat pertama kali daripada spesies ini. Struktur sebatian telah dielusidasi berdasarkan data spektroskopi, terutamanya 1D-NMR, 2D-NMR dan juga perbandingan dengan kajian literatur.
\end{abstract}

Kata kunci: flavonoid, flavonol, kaempferol, quercetin, Uncaria cordata

\section{Introduction}

The genus Uncaria (Rubiaceae) is well known for centuries among medicinal practitioners due to its medicinal properties and ability in healing various diseases such as diarrhea, dysentery, fevers, diabetes and others. Many studies have been carried out scientifically for its pharmacological activities on Uncaria species [1]. For example, Uncaria tomentosa which is widely explored has been proven to have anticancer, anti-inflammatory and other biological properties. A biological study on five species of Malaysian Uncaria including Uncaria longiflora var. pteropoda, Uncaria acida, Uncaria lucida, Uncaria callophylla and Uncaria cordata have indicated that they are rich sources of antioxidants and potential anti-diabetic agents which may be used in the prevention and control of type II diabetes [2]. 


\section{Nur Hakimah et al: ISOLATION OF FLAVONOLS FROM THE STEMS OF MALAYSIAN Uncaria cordata var. ferruginea (BLUME) RIDSD.}

Uncaria is amongst the genera known for its alkaloid content. Previously, we have reported the isolation of two new heteroyohimbine-type oxindole alkaloids, namely rauniticine-allo-oxindole B and rauniticinic-allo acid $\mathrm{B}$ along with five of their stereoisomers including four pentacyclic oxindole alkaloids, isopteropodine, pteropodine, uncarine F and isopteropodic acid from Malaysian Uncaria longiflora var. pteropoda [3 - 5]. In contrast, the non-alkaloid constituents have not been widely reported from Uncaria genus. Lately, the isolation of flavonoids and other chemical constituents present in Uncaria have gained more interest. The flavonoids reported from the genus are mostly isolated from Uncaria gambir particularly flavane derivatives including flavan-3-ols and their dimers [6]. Recently, we have reported the isolation of a novel flavonoid, (-)-2R, 3R-3,5,4'-trihydoxyflavan-[6,7:5",6"]-2"pyranone named uncariechin, along with (-)-epiafzelechin and (-)-epicatechin from the methanol extract of the leaves of Uncaria longiflora var. pteropoda [7]. Therefore, continuing our interest on the phytochemicals from Uncaria, the isolation of two flavonols, quercetin (1) and kaempferol (2) from the stems of Malaysian Uncaria cordata var. ferruginea was reported in this study.

\section{General}

\section{Materials and Methods}

Column chromatography packed with Sephadex LH-20 was carried out and flavonoids were detected on thin layer chromatography (TLC) stained with aluminium chloride $\left(\mathrm{AlCl}_{3}\right)$ reagent. A positive result was indicated by the observation of yellow spots visualized under UV light at $365 \mathrm{~nm}$. Mass spectra were measured on an Agilent 1100 Series Technologies HPLC-TOF LC/MS, where the analysis for compound $\mathbf{1}$ was run in the positive mode, while compound 2 was analysed in the negative mode. The ultraviolet (UV) spectra were obtained in methanol on a Shimadzu UV-Vis 160i. The infrared (IR) data was recorded on a Perkin Elmer model FT-IR spectrometer as KBr disks. ${ }^{1} \mathrm{H}$ and ${ }^{13} \mathrm{C}$-NMR data for compound 1 was obtained in acetone- $d_{6}$ on Bruker 600 Ultrashield NMR spectrometer measured at 600 and $150 \mathrm{MHz}$, respectively while ${ }^{1} \mathrm{H}-\mathrm{NMR}$ and ${ }^{13} \mathrm{C}-\mathrm{NMR}$ data for compound 2 was obtained in MeOD on Bruker 500 Ultrashield NMR spectrometer measured at 500 and $125 \mathrm{MHz}$, respectively.

\section{Plant material}

Stems of Uncaria cordata var. ferruginea was collected from Hutan Pasir Raja, Terengganu in December 2011 and was identified by Dr. Shamsul Khamis (Universiti Putra Malaysia). The voucher specimens were deposited at the Herbarium of Institute of Bioscience, Universiti Putra Malaysia.

\section{Extraction and isolation of compounds}

Stems of Malaysian Uncaria cordata var. ferruginea were cut into small pieces, air-dried and ground into fine powder. The finely ground stems were then weighed and soaked in methanol for 72 hours at room temperature. The solvent was evaporated off under reduced pressure by using a rotary evaporator. Then the extract was dissolved with methanol and water (1:1) before being subjected to liquid-liquid partitioning using chloroform and ethyl acetate. The ethyl acetate fraction $(9.8 \mathrm{~g}$ ) was further fractionated using a column packed with Sephadex LH-20 employing $\mathrm{CHCl}_{3}: \mathrm{MeOH}(9: 1)$ as the solvent system to give four sub-fractions. Based on their TLC profiles, flavonoids were detected in sub-fractions $\mathrm{f} 2$ and $\mathrm{f} 4$ by using aluminium chloride reagent. Repeated column chromatography of these two sub-fractions using Sephadex LH-20 successfully yielded compound $\mathbf{1}$ and compound $\mathbf{2}$.

\section{Results and Discussion}

Compound 1 was isolated as a yellow amorphous solid with melting point $316{ }^{\circ} \mathrm{C}$. The mass spectrum of this compound showed a molecular ion $[\mathrm{M}+\mathrm{H}]^{+}$peak at $\mathrm{m} / \mathrm{z} 303$ which corresponded to the molecular formula $\mathrm{C}_{15} \mathrm{H}_{10} \mathrm{O}_{7}$. Its UV absorptions maxima at 295, 338 and $385 \mathrm{~nm}$ were found to be in agreement with a flavonol-type compound [7]. The IR spectrum displayed absorption bands at 3411, 1665 and $1615 \mathrm{~cm}^{-1}$ indicating the presence of functional groups of $\mathrm{OH}, \mathrm{C}=\mathrm{O}$ and $\mathrm{C}=\mathrm{C}$ aromatic, respectively. The ${ }^{1} \mathrm{H}$ NMR spectrum of compound $\mathbf{1}$ showed the characteristic signals of flavonoid-type compound with $\mathrm{ABX}$ system. In A-ring system, two doublet peaks of metacoupled aromatic protons present at $\delta 6.28(1 \mathrm{H}, \mathrm{d}, J=2.4 \mathrm{~Hz})$ and at $\delta 6.54(1 \mathrm{H}, \mathrm{d}, J=2.4 \mathrm{~Hz})$ were assigned as $\mathrm{H}$ 6 and $\mathrm{H}-8$, respectively. The rest of proton signals belonging to the ring-B system appeared at $\delta 7.01(1 \mathrm{H}, \mathrm{d}, J=8.4$ $\left.\mathrm{Hz}, \mathrm{H}-5^{\prime}\right), 7.72\left(1 \mathrm{H}, \mathrm{dd}, J=8.4,2.4 \mathrm{~Hz}, \mathrm{H}-6\right.$ ') and $7.85\left(1 \mathrm{H}, \mathrm{d}, J=2.4 \mathrm{~Hz}, \mathrm{H}-2^{\prime}\right)$. Its COSY spectrum showed the $\mathrm{H}-\mathrm{H}$ correlation indicating $\mathrm{H}-5^{\prime}$, and $\mathrm{H}-6$ ' to be neighbouring protons. Its ${ }^{13} \mathrm{C}$ NMR spectrum showed the presence of 15 carbon signals which were typical of a flavonol skeleton. The most downfield signal at $\delta 175.67$ was attributed 
to carbonyl C-4 due to electron withdrawing oxygen and anisotropic effects. In addition, five oxyaryl carbons observed at $\delta 135.85,144.97,147.51,161.45$ and 164.16 were attributed to C-3, C-3', C-4', C-5, and C-7. Four quaternary carbons at $\delta 103.23,122.86,146.05$ and 156.90 were assigned as C-10, C-1', C-2 and C-9, respectively. The rest of the signals at $\delta 93.57,98.29,114.87,115.34$ and 120.56 were subsequently determined as aromatic methine carbons C-8, C-6, C-2', C-5' and C-6', respectively which are confirmed by HMQC correlations. All carbon assignments were further confirmed by HMBC and NOESY correlations. In short, the characterization of compound $\mathbf{1}$ is given below.

Pale yellow amorphous solid, wt: $3.2 \mathrm{mg} ; \mathrm{MS} \mathrm{m} / z=303[\mathrm{M}+\mathrm{H}]^{+}, \mathrm{C}_{15} \mathrm{H}_{10} \mathrm{O}_{7}$; $\mathrm{UV}(\mathrm{MeOH}) \lambda_{\max } \mathrm{nm}$ : 295, 338, 385; IR (KBr) $v_{\max } \mathrm{cm}^{-1}: 3411$ (free $\left.\mathrm{OH}\right), 1665(\mathrm{C}=\mathrm{O}), 1615\left(\mathrm{C}=\mathrm{C}\right.$ aromatic); ${ }^{1} \mathrm{H}$ NMR (Acetone- $\left.\mathrm{d}_{6}, 600 \mathrm{MHz}\right) \delta \mathrm{ppm}$ : $12.19(1 \mathrm{H}, \mathrm{br} \mathrm{s}, \mathrm{OH}), 7.85(1 \mathrm{H}, \mathrm{d}, J=2.0 \mathrm{~Hz}, \mathrm{H}-2$ ') $7.72(1 \mathrm{H}, \mathrm{dd}, J=8.5,2.0 \mathrm{~Hz}, \mathrm{H}-6$ ') $7.01(1 \mathrm{H}, \mathrm{d}, J=8.5 \mathrm{~Hz}$, H-5'), $6.54(1 \mathrm{H}, \mathrm{d}, 2.0 \mathrm{~Hz}, \mathrm{H}-8), 6.28(1 \mathrm{H}, \mathrm{d}, 2.0 \mathrm{~Hz}, \mathrm{H}-6) ;{ }^{13} \mathrm{C}$ NMR (Acetone-d $\left.6,150 \mathrm{MHz}\right) \delta \mathrm{ppm}: 175.67$ $(\mathrm{C}=\mathrm{O}), 164.16$ (C-7), 161.45 (C-5), 156.90 (C-9), 147.51 (C-4'), 146.05 (C-2), 144.97 (C-3'), 135.85 (C-3), 122.86 (C-1'), 120.56 (C-6'), 115.34 (C-5'), 114.87 (C-2'), 103.23 (C-10), 98.29 (C-6), 93.57 (C-8). Thus, based on the 1D and 2D NMR spectral data, as well as comparison with the literature [8], compound $\mathbf{1}$ was identified as quercetin.

Compound 2 was isolated as yellow amorphous powder with melting point $277^{\circ} \mathrm{C}$. Its mass spectrum showed a molecular ion $[\mathrm{M}-\mathrm{H}]^{-}$peak at $\mathrm{m} / \mathrm{z} 285$ which corresponds to the molecular formula $\mathrm{C}_{15} \mathrm{H}_{10} \mathrm{O}_{6}$. Its $\mathrm{UV}$ absorptions at 310 and $380 \mathrm{~nm}$ were indicative of a flavonol-type compound. The IR spectrum displayed absorption bands at 3324, 1660 and $1614 \mathrm{~cm}^{-1}$ which were due to the functional groups of $\mathrm{OH}, \mathrm{C}=\mathrm{O}$, and $\mathrm{C}=\mathrm{C}$ aromatic, respectively. The ${ }^{1} \mathrm{H}$ NMR spectrum of this compound showed proton signals of a typical flavonol-type compound with ABX system (6$8 \mathrm{ppm})$. For the A-ring protons, two doublet peaks observed at $\delta 6.18(1 \mathrm{H}, \mathrm{d}, J=2 \mathrm{~Hz})$ and at $\delta 6.39(1 \mathrm{H}, \mathrm{d}, J=2$ $\mathrm{Hz}$ ) were assigned as H-6 and H-8, respectively. Both of these protons were meta-coupled as indicated by their coupling constant value. In the B-ring system, proton signals appeared as a pair of doublet of doublets at $\delta 6.90(2 \mathrm{H}$, dd, $J=7,2 \mathrm{~Hz}, \mathrm{H}-3^{\prime}, \mathrm{H}-5^{\prime}$ ') and at $\delta 8.09$ (2H, dd, $J=7,2 \mathrm{~Hz}, \mathrm{H}-2^{\prime}, \mathrm{H}-6$ '). These protons were ortho-coupled based on their $J$ values and were adjacent to each other as was evident from the COSY spectrum. Its ${ }^{13} \mathrm{C}$ NMR spectrum exhibited 13 carbons signal attributed to 15 carbons with the peak at $\delta 129.27$ representing equivalent carbons C-2' and C-6' and the peak at $\delta 114.89$ representing equivalent carbons C-3' and C-5'. A very downfield signal at $\delta$ 175.95 was attributed to carbonyl C-4 due to electron withdrawing oxygen and anisotropic effect. In addition, four oxyaryl carbons observed at $\delta 135.72,159.13,161.10$ and 164.17 were attributed to C-3, C-4', C-5 and C-7, respectively. Four quaternary carbons at $\delta 103.14,122.33,146.62$ and 156.84 were then assigned as $\mathrm{C}-10, \mathrm{C}-1$ ', $\mathrm{C}-2$ and C-9, respectively. The rest of the carbon signals observed at $\delta 93.07$ (C-8), 97.86 (C-6), 114.89 (C-3', C-5'), and 129.27 (C-2', C-6') were methine carbons. The carbon assignments were confirmed by HMQC and HMBC data. The characterization of compound $\mathbf{2}$ is given below.

Pale yellow amorphous solid, wt: $1.3 \mathrm{mg}$; MS $m / z=285[\mathrm{M}-\mathrm{H}] ; \mathrm{C}_{15} \mathrm{H}_{10} \mathrm{O}_{7}$; UV (MeOH) $\lambda_{\max } \mathrm{nm}$ : 310, 380; IR $(\mathrm{KBr}) v_{\max } \mathrm{cm}^{-1}: 3324($ free $\mathrm{OH}), 1660(\mathrm{C}=\mathrm{O}) 1614\left(\mathrm{C}=\mathrm{C}\right.$ aromatic); ${ }^{1} \mathrm{H}$ NMR $(\mathrm{MeOD}, 500 \mathrm{MHz}) \delta \mathrm{ppm}: 8.09(2 \mathrm{H}$, dd, $J=8.9,2.0 \mathrm{~Hz}, \mathrm{H}-2^{\prime}, \mathrm{H}^{-6}$ '), 6.90 (2H, dd, $J=8.9,2.0 \mathrm{~Hz}, \mathrm{H}-3$ ', H-5'), 6.39 (1H, d, $\left.J=2.0 \mathrm{~Hz}, \mathrm{H}-8\right), 6.18(1 \mathrm{H}$, $\mathrm{d}, J=2.0 \mathrm{~Hz}, \mathrm{H}-6) ;{ }^{13} \mathrm{C}$ NMR (MeOD, $\left.150 \mathrm{MHz}\right) \delta \mathrm{ppm}: 175.95(\mathrm{C}=\mathrm{O}), 164.17$ (C-7), $161.10(\mathrm{C}-5), 159.13(\mathrm{C}-$ 4'), 156.84 (C-9), 146.62 (C-2), 135.72 (C-3), 129.27 (C-2', C-6'), 122.33 (C-1'), 114.89 (C-3', C-5'), 103.14 (C10), 97.86 (C-6), 93.07 (C-8). On the basis of spectral data and comparison with literature [9], compound 2 was identified as 3,4',5,7-tetrahydroxyflavone or kaempferol.

Table 1 shows the ${ }^{13} \mathrm{C}$ NMR data compounds $\mathbf{1}$ and $\mathbf{2}$ along with literature values. Figure 1 shows the structure of the flavonoids. 
Nur Hakimah et al: ISOLATION OF FLAVONOLS FROM THE STEMS OF MALAYSIAN Uncaria cordata var. ferruginea (BLUME) RIDSD.

Table $1 .{ }^{13} \mathrm{C}$ NMR data for compounds 1 and 2

\begin{tabular}{|c|c|c|c|c|c|}
\hline \multirow[b]{2}{*}{ Position } & \multicolumn{2}{|c|}{ Compound 1} & \multicolumn{2}{|c|}{ Compound 2} & \multirow[b]{2}{*}{$\begin{array}{c}\delta_{\mathrm{C}}(\mathrm{ppm}) \\
{\text { in } \mathrm{DMSO}^{\mathrm{b}}}^{\mathrm{b}}\end{array}$} \\
\hline & $\delta_{\mathrm{C}}(\mathbf{p p m})$ & $\begin{array}{c}\delta_{\mathrm{C}}(\mathrm{ppm}) \\
\text { in } \mathrm{MeOD}^{\mathrm{a}}\end{array}$ & Position & $\delta_{\mathrm{C}}(\mathbf{p p m})$ & \\
\hline 2 & 146.05 & 147.8 & 2 & 146.62 & 147.3 \\
\hline 3 & 135.85 & 137.3 & 3 & 135.72 & 136.0 \\
\hline 4 & 175.67 & 177.4 & 4 & 175.95 & 176.4 \\
\hline 5 & 161.45 & 162.4 & 5 & 161.10 & 161.2 \\
\hline 6 & 98.25 & 99.4 & 6 & 97.86 & 98.7 \\
\hline 7 & 164.16 & 165.6 & 7 & 164.17 & 164.4 \\
\hline 8 & 93.57 & 94.5 & 8 & 93.07 & 94.0 \\
\hline 9 & 156.90 & 158.3 & 9 & 156.84 & 156.7 \\
\hline 10 & 103.23 & 104.5 & 10 & 103.14 & 103.5 \\
\hline 1 ' & 122.86 & 124.0 & 1 ' & 122.33 & 122.1 \\
\hline 2 & 114.87 & 116.1 & 2 ' & 129.27 & 130.0 \\
\hline 3, & 144.97 & 146.2 & 3, & 114.89 & 115.9 \\
\hline $4^{\prime}$ & 147.51 & 148.7 & 4 ' & 159.13 & 159.7 \\
\hline 5 & 115.34 & 116.3 & 5 & 114.89 & 115.9 \\
\hline $6{ }^{\prime}$ & 120.56 & 121.5 & $6{ }^{\prime}$ & 129.27 & 130.0 \\
\hline
\end{tabular}

${ }^{\mathrm{a}}[8],{ }^{\mathrm{b}}[9]$<smiles>O=c1c(O)c(-c2ccc(O)c(O)c2)oc2cc(O)cc(O)c12</smiles>

1<smiles>O=c1c(O)c(-c2ccc(O)cc2)oc2cc(O)cc(O)c12</smiles>

2

Figure 1. Structure of flavonols isolated from the stems of Malaysian Uncaria cordata var. ferruginea: (1) Quercetin, (2) Kaempferol

\section{Conclusion}

Phytochemical study of the methanolic stem extract of Malaysian Uncaria cordata var. ferruginea has led to the isolation of two flavonols, quercetin and kaempferol along with other phenolic compounds and terpenes. The structure of the compounds was elucidated on the basis of spectroscopic data. The presence of other non-alkaloidal constituents should be further explored in order to justify their chemotaxonomic significance in the Uncaria genus. 


\section{Acknowledgement}

We wish to thank the Ministry of Science, Technology and Innovation Malaysia (MOSTI) for research grant under E-Science Fund (02-01-01-SF0563) as well as Universiti Teknologi MARA for the facilities provided.

\section{References}

1. Heitzman, M. E., Neto, C. C., Winiarz, E., Vaisberg, A. J. and Hammond, G. B. (2005). Ethnobotany, phytochemistry and pharmacology of Uncaria (Rubiaceae). Phytochemistry, 66: 5 - 29.

2. Ahmad, R., Hashim, M. H., Noor, M. Z., Ismail, N. H., Salim, F., Lajis, N. H. and Shaari, K. (2011). Antioxidant and antidiabetic potential of Malaysian Uncaria. Research Journal of Medicinal Plant, 5 (5): 587 $-595$.

3. Salim, F. and Ahmad, R. (2010). Isopteropodic acid from Malaysia Uncaria longiflora var. pteropoda. World Applied Sciences Journal, 10 (11): 1334 - 1337.

4. Salim, F. and Ahmad, R. (2011). Alkaloids from Malaysian Uncaria longiflora var. pteropoda. Biochemical Systematics and Ecology, 39 (2): 151 - 152.

5. Salim, F., Ismail, N. H., Awang, K. and Ahmad, R. (2011). Rauniticine-allo-oxindole B and Rauniticinic-allo acid B, new heteroyohimbine-type oxindole alkaloids from the stems of Malaysian Uncaria longiflora var. pteropoda. Molecules, 16: 6541 - 6548.

6. Andre, N., Wang, X., He, Y., Pan, G., Kojo, A. and Liu, Y. (2013). A review of the occurrence of non-alkaloid constituents in Uncaria species and their structure-activity relationships. American Journal of Biomedical and Life Sciences, 1 (4): $79-98$.

7. Salim, F., Zain, M. M., Ridzuan, M. S. M., Langat, M., Mullholand, D. and Ahmad, R. (2013). Flavan-3-ols from the leaves of Malaysian Uncaria longiflora var. pteropoda (Miq.) Ridsd. Phytochemistry Letters, 6: 236 240 .

8. Jash, S. K., Roy, R. and Gorai, D. (2014). Bioactive constituents from Bauhinia variegata Linn. International Journal of Pharmaceutical and Biomedical Research, 5 (2): 51 - 54.

9. Li, S. G., Dong, X. X., Shan, Y. J., Liang, Z. M., Xun, L. L. and Yuan, J. Q. (2011). Non-alkaloid components from Uncaria sinensis (Oliv.) Havil. and their chemotaxonomic significance. Journal of Medicinal Plants Research, 5 (19): 4962 - 4967. 